Archive for

Organic Chemistry

Arkivoc 2020, part viii, 176-184

\title{
The extended Vilsmeier reaction of dimethoxy-activated indoles
}

\author{
Darryl B. McConnell, Glenn C. Condie, Naresh Kumar, and David StC. Black*
}

School of Chemistry, UNSW Sydney, NSW 2052, Australia

Email:d.black@unsw.edu.au

Received 10-16-2020

Accepted 12-15-2020

Published on line $12-28-2020$

\section{Abstract}

The activated dimethoxyindoles 7, 9, 14 and 17 undergo reaction with 3-dimethylaminopropenal 1 and phosphoryl chloride to give high yields of the indolyl-propenals 8, 10-13, 15-16, and 18-19, with electrophilic substitution taking place at C2, C4 and C7. This extended Vilsmeier methodology provides effective functionalisation of indoles with a propenyl substituent in a single step.

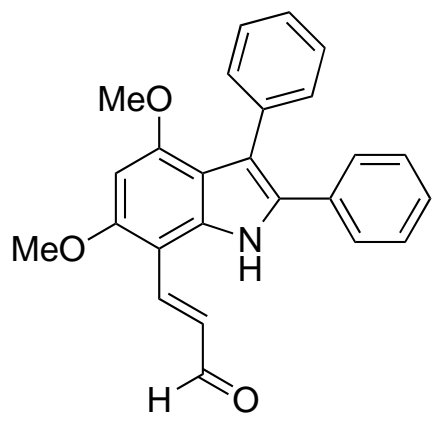<smiles>COc1cc(OC)c2c(-c3ccc(Cl)cc3)c(/C=C/C=O)[nH]c2c1</smiles><smiles>COC(=O)c1cc2c(/C=C/C=O)c(OC)cc(OC)c2[nH]1</smiles><smiles>COc1cc(OC)c2c(-c3ccc(Cl)cc3)c(/C=C/C=O)[nH]c2c1/C=C/C=O</smiles>

Keywords: Vilsmeier reaction, 3-dimethylaminopropenal, phosphoryl chloride, indoles, electrophilic substitution, iminium cations 


\section{Introduction}

The extended Vilsmeier reaction refers to the use of the vinylogous tertiary amide 3-dimethylaminopropenal 1 in combination with phosphoryl chloride, to generate a reactive intermediate, believed to be the 3-chloro-2propeniminium salt $\mathbf{2}$, which undergoes attack by soft nucleophiles at $\mathrm{C} 3$ leading to $\alpha, \beta$-unsaturated aldehyde products. ${ }^{1}$ The detailed mechanism is consequently the vinylogous equivalent of that relating to the fundamental Vilsmeier reaction. Gossman and Franck performed the extended Vilsmeier reaction on 3,4diethylpyrrole 3 to obtain the vinyl aldehyde 4 (Scheme 1). ${ }^{2}$ The conversion of indole 5 into the 3-(indol-3yl)propenal 6 was carried out in a related version of the extended Vilsmeier reaction, using 3-methyl-3phenylaminopropenal and hexachlorocyclophosphazatriene, ${ }^{3}$ but this and related compounds have also been prepared using a variety of other reactions (Scheme 1). ${ }^{4-13}$

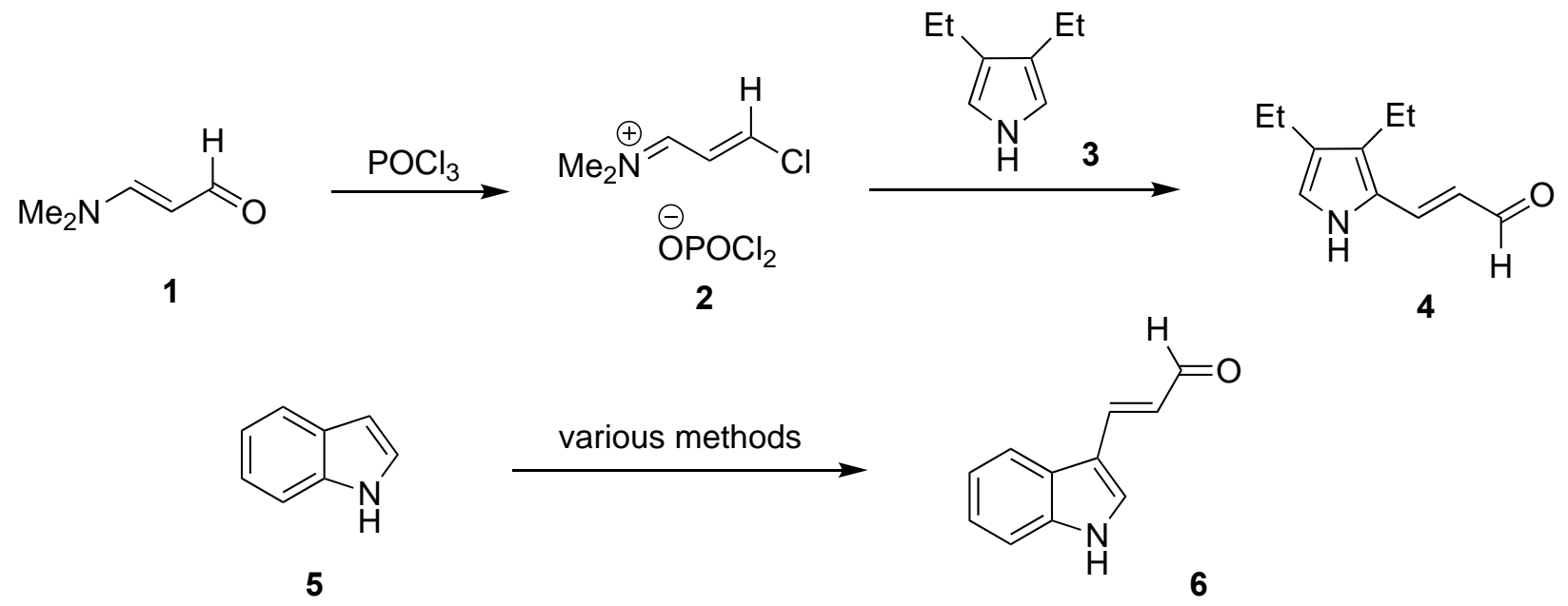

Scheme 1. Formation of 2-pyrrolyl- and 3-indolyl-propenals 4 and 6.

It is an advantage of the extended Vilsmeier reaction that the complete side chain can be attached to the heterocycle in a single step. The normal Vilsmeier reaction has been very successfully applied to the activated 4,6-dimethoxyindoles ${ }^{14,15}$ and 5,7-dimethoxyindoles ${ }^{16}$ to give the related 7- and 4-carbaldehydes respectively. It was therefore of interest to investigate the extended version of this reaction for these activated indoles.

\section{Results and Discussion}

The 4,6-dimethoxy-2,3-diphenylindole 7 was reacted with 3-dimethylaminopropenal 1 and phosphoryl chloride and following work-up with aqueous sodium hydroxide afforded the orange-red 7-substituted indole 8 in $97 \%$ yield (Scheme 2 ).

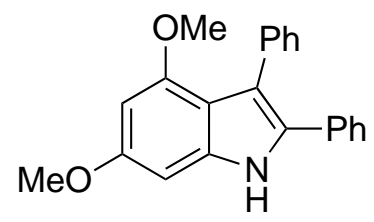

7

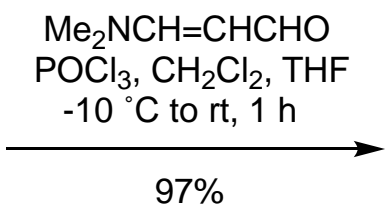

$97 \%$<smiles>COc1cc(OC)c2c(-c3ccccc3)c(-c3ccccc3)[nH]c2c1/C=C/C=O</smiles>

Scheme 2. Formation of 7-indolylpropenal 8. 
However, a similar reaction of the 3-aryl indole $\mathbf{9}$ gave the yellow 2-substituted indole $\mathbf{1 0}$ as the major product in $75 \%$ yield: it was accompanied by a small amount of the isomeric 7-substituted indole 11, which could not be isolated (Scheme 3). The ratio of 2:7 isomers was identified by ${ }^{1} \mathrm{H}$ NMR spectroscopy to be $90: 10$. Compound $\mathbf{1 0}$ was assigned the trans configuration on the basis of the alkenyl proton coupling constant of $15.9 \mathrm{~Hz}$. The result of this reaction is in stark contrast to the outcome of Vilsmeier formylation of compound 9 (and many similar indoles) where the overwhelmingly major product is the 7 -isomer. ${ }^{17}$ In this situation, the indole-7-carbaldehyde oxygen atom is able to form a strong hydrogen bond to the indole $\mathrm{NH}$ proton forming a 6-membered ring, but this is not available for the vinylogous example. The trans-propenal $\mathbf{1 0}$ was observed to undergo isomerization to the dark red cis-propenal $\mathbf{1 2}$ at room temperature in a variety of non-hydrogen bonding solvents and this process was accelerated at higher temperatures. The cis-isomer 12 displayed an alkenyl proton coupling constant of $12.2 \mathrm{~Hz}$ in its ${ }^{1} \mathrm{H}$ NMR spectrum. The cis-structure is presumably stabilized to some extent by formation of a hydrogen bond between the aldehyde oxygen atom and the indole $\mathrm{NH}$ proton to form a 7-membered ring. Treatment of the 3-aryl indole 9 with an excess of 3dimethylaminopropenal 1 and phosphoryl chloride gave the rather insoluble orange 2,7-disubstituted indole 13 in $48 \%$ yield (Scheme 3 ).
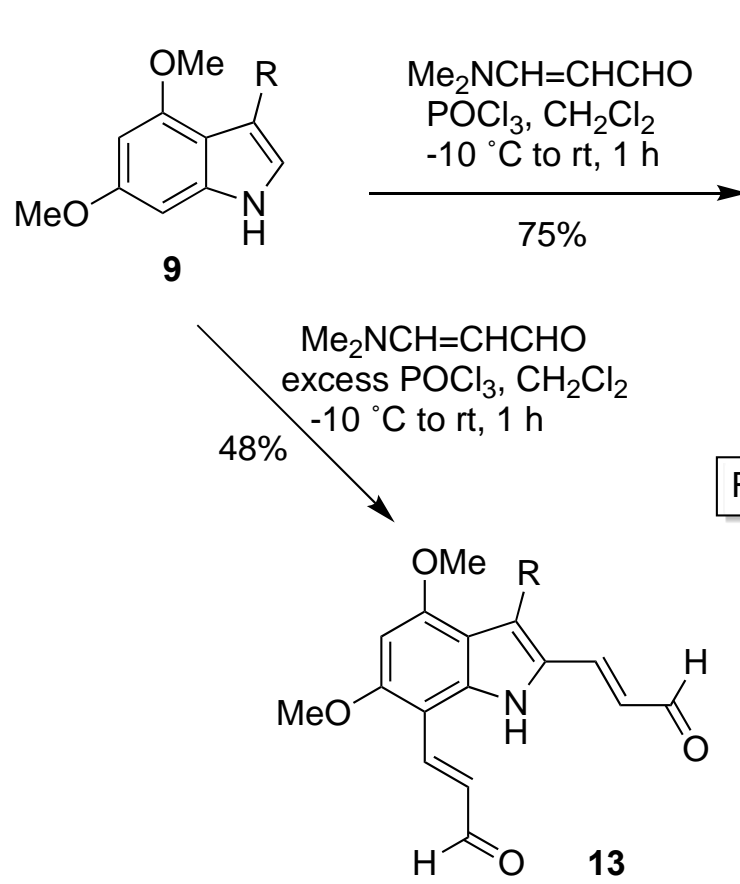

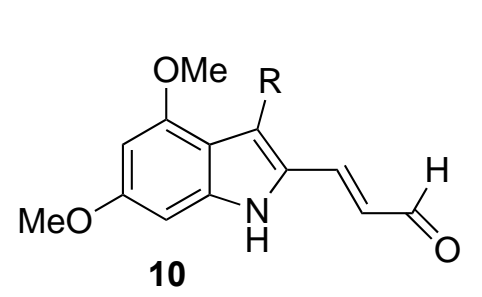

10

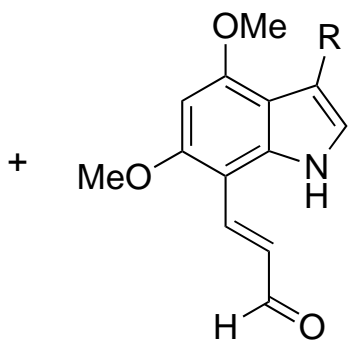

minor product

(not isolated)

11
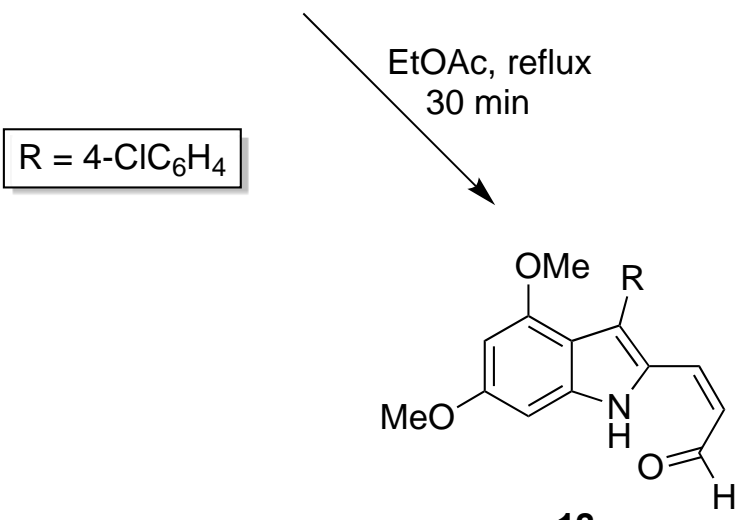

12

Scheme 3. Formation of 2-indolyl-, 7-indolyl- and 2,7-diindolylpropenals 10-13.

The $\mathrm{N}$-methyl indole 14 was prepared by methylation of indole 9, and when treated with 3-dimethylaminopropenal 1 and phosphoryl chloride gave a mixture of the 2- and 7- isomeric propenals 15 and 16 in yields of $77 \%$ and $17 \%$ respectively (Scheme 4 ). In both cases the alkenyl systems were trans, as identified by ${ }^{1} \mathrm{H}$ NMR proton coupling constants of 16.4 and $15.5 \mathrm{~Hz}$ respectively. No isomerization of the transconfiguration of compound $\mathbf{1 5}$ was observed. Furthermore, methylation of the cis-propenal 12 generated compound $\mathbf{1 5}$ as a result of cis-trans isomerization. 
<smiles>[R]c1c[nH]c2cc(OC)cc(OC)c12</smiles>

9 $\mathrm{R}=4-\mathrm{ClC}_{6} \mathrm{H}_{4}$

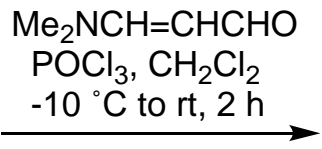

14

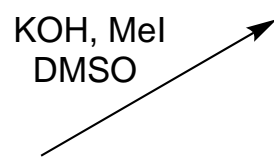

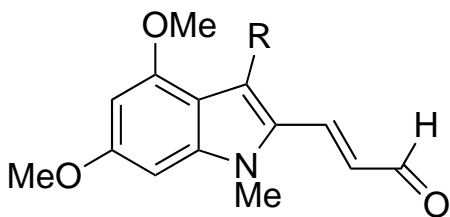

$15(77 \%)$

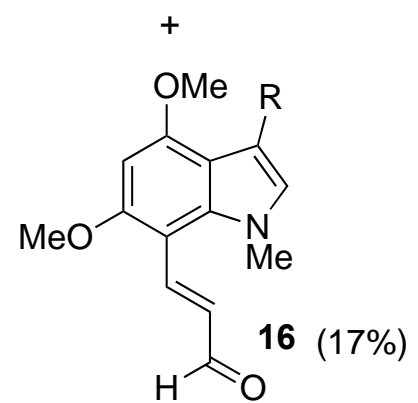

Scheme 4. Formation of 2-indolyl- and 7-indolyl- $N$-methyl-propenals 15 and 16.

The extended Vilsmeier methodology was also applied to methyl 5,7-dimethoxyindole-2-carboxylate 17. Thus, reaction with 3-dimethylaminopropenal 1 and phosphoryl chloride under the same conditions as used in the case of indole 9 gave the 4-indolylpropenal in a 99\% yield, as a 5:1 mixture of the trans-propenal 18 and the cis-propenal 19 respectively (Scheme 5). The respective structures showed ${ }^{1} \mathrm{H}$ NMR proton coupling constants of 16.2 and $11.3 \mathrm{~Hz}$ for the alkenyl protons. Substitution occurred exclusively at C4 and not at all at C3: this is consistent with similar reported Vilsmeier formylation behaviour. ${ }^{16}$ The trans-isomer 18 was isolated as crimson rhombs by recrystallization from dichloromethane/light petroleum. Furthermore, no isomerization to the cis-isomer 19 was observed on heating.

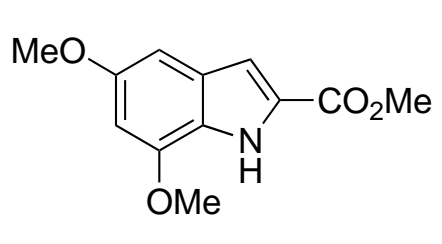

17

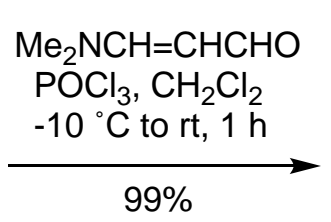

(1)<smiles>COc1cc(OC)c2[nH]c(C(C)=O)cc2c1/C=C/C=O</smiles>

$5: 1$<smiles>COc1cc(OC)c2[nH]c(C(C)=O)cc2c1/C=C\C=O</smiles>

19

Scheme 5. Formation of 4-indolylpropenals 18 and 19.

The various propenylated indoles offer a wide range of further functionalization developments. The early work of Gosmann and Franck was directed to the synthesis of a macrocyclic tetrapyrrole, via acid-catalysed tetramerisation of the allylic alcohol obtained by reduction of their pyrrolylpropenal. ${ }^{2}$ Given our previous conversion of activated indolylmethanols into calix[3]- and calix[4]-arenes, ${ }^{17}$ we carried out preliminary investigations in a search for expanded calixindoles. The various indolylpropenals were reduced with sodium borohydride in a mixture of methanol and tetrahydrofuran, and the crude indolylmethanol products were treated with $p$-toluenesulfonic acid in dichloromethane. No discrete macrocyclic or oligomeric products could be isolated from the resulting polymeric mixtures. A more prolonged investigation of different reaction conditions is needed to try to achieve the formation of expanded calixindoles from the indolylpropenal structures. 


\section{Conclusions}

A variety of indoles, activated by methoxy groups placed at C4 and C6, or C5 and C7, undergo reaction with 3dimethylaminopropenal 1 and phosphoryl chloride to give high yields of the indolyl-propenals resulting from electrophilic substitution taking place at C2, C4 and C7. This extended Vilsmeier methodology provides effective functionalisation of indoles with a propenyl substituent in a single step. These products provide a range of opportunities for further structural variation and development.

\section{Experimental Section}

General. ${ }^{1} \mathrm{H}$ and ${ }^{13} \mathrm{C}$ NMR spectra were recorded on a Bruker $\mathrm{AC} 300 \mathrm{~F}\left({ }^{1} \mathrm{H}: 300 \mathrm{MHz},{ }^{13} \mathrm{C}: 75.5 \mathrm{MHz}\right)$ or a Bruker AM500 spectrometer. The chemical shifts $(\delta)$ and coupling constants $(J)$ are expressed in ppm and hertz respectively. Carbon attributions $\mathrm{C}, \mathrm{CH}, \mathrm{CH}_{2}$ and $\mathrm{CH}_{3}$ were determined by ${ }^{13} \mathrm{C}$, DEPT and $\mathrm{HMQC}$ experiments. Infrared (IR) spectra were recorded on a Mattson Genesis Series FTIR spectrometer using potassium bromide disks, except where specified. Ultraviolet and visible (UV/Vis) spectra were recorded in tetrahydrofuran or methanol using a Carey 100 spectrometer. Mass spectra were recorded on a VG Quattro MS (EI) or a Finnigan MAT (MALDI). High resolution mass spectrometry (HRMS) was carried out at the Research School of Chemistry, Australian National University. Melting points were measured using a Mel-Temp melting point apparatus and are uncorrected. Microanalyses were performed at the UNSW Microanalytical Unit and at the Campbell Microanalytical Laboratory, University of Otago, New Zealand. Column chromatography was carried out using Merck 230-400 mesh silica gel or Merck 70-230 mesh silica gel, whilst preparative TLC was performed using Merck 60GF 254 silica gel.

trans-3-(4,6-Dimethoxy-2,3-diphenylindol-7-yl)propen-1-al (8). The diphenylindole 7 (2.05g, $6.22 \mathrm{mmol})$ and 3-dimethylaminopropenal $1(1.2 \mathrm{~mL}, 11.98 \mathrm{mmol})$ were dissolved together in a mixture of anhydrous dichloromethane $(50 \mathrm{~mL})$ and anhydrous tetrahydrofuran $(1 \mathrm{~mL})$. The resulting solution was stirred at $-10{ }^{\circ} \mathrm{C}$ in an ice-salt bath and phosphoryl chloride $(1.2 \mathrm{ml}, 12.87 \mathrm{mmol})$ was added dropwise. The solution was allowed to warm to room temperature and stirred for a further $1 \mathrm{~h}$. Sodium hydroxide (10\% aqueous solution) was added and the reaction mixture was stirred vigorously for $1.5 \mathrm{~h}$. The mixture was then extracted with ethyl acetate and the organic phase was washed with water, brine and dried $\left(\mathrm{MgSO}_{4}\right)$. The solvent was removed under reduced pressure to yield the trans-propenal $8(2.31 \mathrm{~g}, 97 \%)$ as orange-red rhombs, $\mathrm{mp} 246-247{ }^{\circ} \mathrm{C}$ (from ethanol). IR $\left(V_{\max } \mathrm{cm}^{-1}\right): 3378,1646,1566,1170,977,760,696$. UV/Vis $\left(\lambda_{\max }, \mathrm{nm}, \varepsilon, \mathrm{cm}^{-1} \mathrm{M}^{-1}\right): 262$ (28,800), 337 (15,600), 400 (14,500). ${ }^{1} \mathrm{H}$ NMR (300 MHz, CDCl $): \delta_{\mathrm{H}} 3.81,4.02(6 \mathrm{H}, 2 \mathrm{~s}, \mathrm{OMe}), 6.29(1 \mathrm{H}, \mathrm{s}$, indole H5), $6.78(1 \mathrm{H}, \mathrm{dd}, J 16.3 \mathrm{~Hz}, 7.7 \mathrm{~Hz}, \mathrm{H} 2), 7.26-7.40(10 \mathrm{H}, \mathrm{m}$, aryl), $8.12(1 \mathrm{H}, \mathrm{d}, J 16.3 \mathrm{~Hz}, \mathrm{H} 3), 8.59(1 \mathrm{H}, \mathrm{br}$, $\mathrm{NH}), 9.71(1 \mathrm{H}, \mathrm{d}, J 7.7 \mathrm{~Hz}, \mathrm{CHO}) .{ }^{13} \mathrm{C} \mathrm{NMR}\left(75 \mathrm{MHz}, \mathrm{CDCl}_{3}\right.$ ): $\delta_{\mathrm{C}}$ 56.0, 57.3 (OMe), 89.0 (indole C5), 126.2, 127.0, 128.1, 128.2, 128.7, 129.3, 132.0 (aryl CH, C2), 146.4 (C3), 101.5, 114.3, 116.2, 132.8, 134.0, 135.9, 136.8, 159.1, 159.6 (aryl C), 195.5 (CHO). MS (+El, $m / z, \%): 383$ (M, 45), 366 (100). Anal. calcd for $\mathrm{C}_{25} \mathrm{H}_{21} \mathrm{NO}_{3}: \mathrm{C}_{,} 78.3$; $H, 5.5 ; \mathrm{N}, 3.7$. Found: $C, 78.5 ; \mathrm{H}, 5.8 ; \mathrm{N}, 3.5 \%$.

trans-3-(3-(4'-Chlorophenyl)-4,6-dimethoxyindol-2-yl)propen-1-al (10). The indole 9 (0.14 g, $0.49 \mathrm{mmol})$ and 3-dimethylaminopropenal $1(94 \mu \mathrm{L}, 0.94 \mathrm{mmol})$ were dissolved together in anhydrous dichloromethane (20 $\mathrm{mL})$ and the resulting solution was cooled to $-10{ }^{\circ} \mathrm{C}$ in an ice-salt bath and phosphoryl chloride (94 $\mu \mathrm{L}, 1.01$ mmol) was added dropwise. The solution was allowed to warm to room temperature and stirred for $1 \mathrm{~h}$. Sodium hydroxide (10\% aqueous solution) was added and the reaction mixture was stirred vigorously for 1.5 
h. The solution was extracted with ethyl acetate and the organic phase was washed with water, saturated brine solution and dried $\left(\mathrm{MgSO}_{4}\right)$. The solvent was removed under reduced pressure to yield the transpropenal $10(0.13 \mathrm{~g}, 75 \%)$ as a yellow solid, $\mathrm{mp} 212-214{ }^{\circ} \mathrm{C}$. IR $\left(\mathrm{V}_{\max } \mathrm{cm}^{-1}\right): 3300,1651,1605,1132,667$. UV/Vis $\left(\lambda_{\max }, \mathrm{nm}, \varepsilon, \mathrm{cm}^{-1} \mathrm{M}^{-1}\right): 275(20,800), 402(29,300) .{ }^{1} \mathrm{H} N M R\left(300 \mathrm{MHz}, \mathrm{CDCl}_{3}\right): \delta_{\mathrm{H}} 3.71,3.88(6 \mathrm{H}, 2 \mathrm{~s}, \mathrm{OMe}), 6.17$ $(1 \mathrm{H}, \mathrm{d}, J 1.7 \mathrm{~Hz}$, indole H5), $6.42(1 \mathrm{H}, \mathrm{dd}, J, 15.9,7.4 \mathrm{~Hz}, \mathrm{H} 2), 6.48(1 \mathrm{H}, \mathrm{d}, J 1.7 \mathrm{~Hz}$, indole H7) $7.28(1 \mathrm{H}, \mathrm{d}, J 15.9$ $\mathrm{Hz}, \mathrm{H3}), 7.37,7.41(4 \mathrm{H}, 2 \mathrm{~d}, J 8.6 \mathrm{~Hz}, \operatorname{aryl}), 8.68(1 \mathrm{H}, \mathrm{br}, \mathrm{NH}), 9.52(1 \mathrm{H}, \mathrm{d}, J 7.4 \mathrm{~Hz}, \mathrm{CHO}) .{ }^{13} \mathrm{C} \mathrm{NMR}(75 \mathrm{MHz}$, $\mathrm{CDCl}_{3}$ ): $\delta_{\mathrm{C}} 55.8,56.4$ (OMe), 86.7 (indole C5), 93.8 (indole C7), 124.2 (C2), 140.9 (C3), 128.4, 133.2 (aryl CH), $113.8,128.5,128.7,129.1,132.9,140.7,156.5,161.6$ (aryl C), 193.6 (CHO). MS (+El, $m / z, \%): 343\left(\mathrm{M}^{37} \mathrm{Cl}, 35\right)$, 341 (M $\left.{ }^{35} \mathrm{Cl}, 100\right), 326$ (17), 312 (14), 300 (14), 287 (14), 277 (33). Anal. calcd for $\mathrm{C}_{19} \mathrm{H}_{16} \mathrm{ClNO}_{3}$ : C, 66.8; H, 4.7; $\mathrm{N}, 4.1$. Found: $\mathrm{C}, 66.7 ; \mathrm{H}, 4.9 ; \mathrm{N}, 4.0 \%$.

cis-3-(4-Chlorophenyl-4,6-dimethoxyindol-2-yl)propen-1-al (12). trans-Propen-3-al 10 was heated under reflux in ethyl acetate for $30 \mathrm{~min}$. The resulting isomeric mixture was fractionally recrystallized from ethyl acetate/light petroleum to yield the cis-propen-3-al 12 as a dark red solid, mp 187-188 ${ }^{\circ} \mathrm{C} .{ }^{1} \mathrm{H} \mathrm{NMR} \mathrm{(300} \mathrm{MHz,}$ $\left.\mathrm{CDCl}_{3}\right): \delta_{\mathrm{H}} 3.70,3.85(6 \mathrm{H}, 2 \mathrm{~s}, \mathrm{OMe}), 5.98(1 \mathrm{H}, \mathrm{dd}, J 12.3 \mathrm{~Hz}, 2.3 \mathrm{~Hz}, \mathrm{H} 2), 6.13,6.54(2 \mathrm{H}, 2 \mathrm{~d}, J 1.8 \mathrm{~Hz}$, indole H5 and H7), $6.69(1 \mathrm{H}, \mathrm{dd}, J 12.3 \mathrm{~Hz}, 1.9 \mathrm{~Hz}, \mathrm{H3}), 7.35,7.38(4 \mathrm{H}, 2 \mathrm{~d}, J 9.2 \mathrm{~Hz}, \operatorname{aryl}), 9.45(1 \mathrm{H}, \mathrm{t}, J 1.9 \mathrm{~Hz}, \mathrm{CHO}), 12.23$ $(1 \mathrm{H}, \mathrm{br}, \mathrm{NH}) .{ }^{13} \mathrm{C} \mathrm{NMR}\left(75 \mathrm{MHz}, \mathrm{CDCl}_{3}\right): \delta_{\mathrm{C}} 55.7,56.3$ (OMe), 86.8 (indole C5), 93.8 (indole C7), 116.9 (C2), 134.4 (C3), 128.1, 133.5 (aryl CH), 114.0, 127.4, 128.3, 131.2, 133.8, 139.0, 156.4, 161.8 (aryl C), 190.5 (CHO). $\mathrm{MS}(+\mathrm{El}, \mathrm{m} / \mathrm{z}, \%): 343\left(\mathrm{M}^{37} \mathrm{Cl}, 30\right), 341\left(\mathrm{M}^{35} \mathrm{Cl}, 100\right), 326$ (15), 300 (20), 277 (35).

trans-3-[3-(4-Chlorophenyl)-4,6-dimethoxy-7-(3-propen-1-al)indol-2-yl]propen-1-al (13). The indole 9 (2.02 $\mathrm{g}, 7.02 \mathrm{mmol}$ ) and 3-dimethylaminopropenal $1(1.50 \mathrm{~mL}, 15.0 \mathrm{mmol})$ were dissolved together in anhydrous dichloromethane $(100 \mathrm{~mL})$ and the resulting solution was cooled to $-10^{\circ} \mathrm{C}$ in an ice-salt bath. Phosphoryl chloride $(1.50 \mathrm{~mL}, 16.1 \mathrm{mmol})$ was added dropwise. The solution was allowed to warm to room temperature and stirred for $5 \mathrm{~h}$. Sodium hydroxide (10\% aqueous solution) was added and the reaction mixture was stirred vigorously overnight. The remaining solution was extracted with ethyl acetate/tetrahydrofuran and the organic phase was washed with water, saturated brine solution and dried $\left(\mathrm{MgSO}_{4}\right)$. The solvent was removed under reduced pressure to yield the dipropenal $13(1.34 \mathrm{~g}, 48 \%)$ as an orange solid. Recrystallization from acetone resulted in orange needles, $\mathrm{mp} 269-270{ }^{\circ} \mathrm{C}$. IR $\left(\mathrm{v}_{\max } \mathrm{cm}^{-1}\right): 3380,3360,1670,1660,1585,1295,1285$, 1140, 1110. UV/Vis $\left(\lambda_{\max }, \mathrm{nm}, \varepsilon, \mathrm{cm}^{-1} \mathrm{M}^{-1}\right): 220(17,500), 272(22,100), 298(11,000), 383(28,300) .{ }^{1} \mathrm{H} N M R$ (300 MHz, $\mathrm{d}_{6}$-DMSO): $\delta_{\mathrm{H}} 3.90,4.13(6 \mathrm{H}, 2 \mathrm{~s}, \mathrm{OMe}), 6.60(1 \mathrm{H}, \mathrm{s}$, indole H5), 7.03-7.11 (2H, m, H2), $7.41(1 \mathrm{H}, \mathrm{d}, J$ $15.9 \mathrm{~Hz}, \mathrm{H3}), 7.50,7.59(4 \mathrm{H}, 2 \mathrm{~d}, J 7.7 \mathrm{~Hz}, \operatorname{aryl}), 8.33(1 \mathrm{H}, \mathrm{d}, J 15.4 \mathrm{~Hz}, \mathrm{H3}), 9.65,9.74(2 \mathrm{H}, 2 \mathrm{~d}, J 7.7 \mathrm{~Hz}, \mathrm{CHO})$, $11.59(1 \mathrm{H}, \mathrm{s}, \mathrm{NH}) .{ }^{13} \mathrm{C} N M R\left(75 \mathrm{MHz}, \mathrm{d}_{6}\right.$-DMSO): $\delta_{\mathrm{C}} 59.7,60.5$ (OMe), 93.4 (indole C5), 131.5, 136.8 (aryl CH), 130.2, 131.9, 143.5, 149.1, alkenyl CH), 103.8, 115.8, 127.4, 134.0, 136.0, 136.2, 143.4, 162.2, 164.9 (aryl C), 198.0, 198.6 (CO). MS (+El, m/z, \%): $397\left(\mathrm{M}^{37} \mathrm{Cl}, 25\right), 395\left(\mathrm{M}^{35} \mathrm{Cl}, 70\right), 378(100), 364$ (50), 114 (60). Anal. calcd for $\mathrm{C}_{22} \mathrm{H}_{18} \mathrm{ClNO}_{4} .0 .5 \mathrm{H}_{2} \mathrm{O}: \mathrm{C}, 65.3 ; \mathrm{H}, 4.7 ; \mathrm{N}, 3.5$. Found: $\mathrm{C}, 65.6 ; \mathrm{H}, 4.9 ; \mathrm{N}, 3.2 \%$.

3-(4-Chlorophenyl)-4,6-dimethoxy- $\mathbf{N}$-methylindole (14). The indole $9(0.51 \mathrm{~g}, 1.78 \mathrm{mmol})$ and crushed potassium hydroxide were dissolved together in dimethylsulfoxide $(20 \mathrm{~mL})$ and the solution was stirred at room temperature for $10-15 \mathrm{~min}$. Methyl iodide $(0.13 \mathrm{~mL}, 2.1 \mathrm{mmol})$ was added and the mixture stirred for 1 h. Water was added and the resulting precipitate was collected to yield $N$-methylindole $14(0.46 \mathrm{~g}, 87 \%)$ as a pale yellow solid. Recrystallization from ethyl acetate/light petroleum resulted in yellow rhombs, mp 135-136 ${ }^{\circ} \mathrm{C} . \mathrm{IR}\left(v_{\max } \mathrm{cm}^{-1}\right): 1582,1211,1146,837,811$. UV/Vis $\left(\lambda_{\max }, \mathrm{nm}, \varepsilon, \mathrm{cm}^{-1} \mathrm{M}^{-1}\right): 226(\varepsilon 28,100), 279 \mathrm{~nm}(16,700) .{ }^{1} \mathrm{H}$ NMR $\left(300 \mathrm{MHz}, \mathrm{CDCl}_{3}\right): \delta_{\mathrm{H}} 3.78,3.85,3.94(9 \mathrm{H}, \mathrm{OMe}, \mathrm{NMe}), 6.31,6.44(2 \mathrm{H}, \mathrm{d}, J 2.0 \mathrm{~Hz}, \mathrm{H} 5, \mathrm{H} 7), 6.92(1 \mathrm{H}, \mathrm{s}$, $\mathrm{H} 2$ ), $7.46\left(4 \mathrm{H}\right.$, dd, J $2.7 \mathrm{~Hz}, 8.5 \mathrm{~Hz}$, aryl). ${ }^{13} \mathrm{C} N M R$ (75 MHz, d 6 -DMSO): $\delta_{\mathrm{C}} 32.6$ (NMe), 54.9, 55.3 (OMe), 85.9 (C5), 91.9 (C7), 126.2 (C2), 127.4, 130.3 (aryl CH), 109.4, 114.7, 129.6, 134.8, 138.9, 154.0, 156.9 (aryl C). MS 
(+El, m/z, \%): $303\left(\mathrm{M}^{37} \mathrm{Cl}, 30\right), 301\left(\mathrm{M}^{35} \mathrm{Cl}, 100\right), 286$ (25), 258 (16), 251 (85), 236 (16). Anal. calcd for $\mathrm{C}_{17} \mathrm{H}_{16} \mathrm{ClNO}_{2}$ : C, 67.7; $\mathrm{H}, 5.3 ; \mathrm{N}, 4.6$. Found: $\mathrm{C}, 67.5 ; \mathrm{H}, 5.4 ; \mathrm{N}, 4.5 \%$.

trans-3-[3-(4-Chlorophenyl)-4,6-dimethoxy-1-methylindol-2-yl]propen-1-al (15) and trans-3-[3-(4chlorophenyl)-4,6-dimethoxy-1-methylindol-7-yl]propen-1-al (16). The N-methylindole 14 (200 mg, 0.66 mmol) and 3-dimethylaminopropenal 1 (80 $\mu \mathrm{L}, 0.80 \mathrm{mmol})$ were dissolved together in anhydrous dichloromethane $(20 \mathrm{~mL})$ and the soution cooled to $-10{ }^{\circ} \mathrm{C}$ with an ice-salt bath. Phosphoryl chloride $(80 \mu \mathrm{L}$, $0.85 \mathrm{mmol}$ ) was added slowly and the solution warmed to room temperature and stirred for a further $2 \mathrm{~h}$. Sodium hydroxide (10\% aqueous solution) was added and the reaction mixture was stirred overnight. The mixture was extracted with dichloromethane, the extract washed with water, saturated brine solution and dried $\left(\mathrm{MgSO}_{4}\right)$. The solvent was removed under reduced pressure and the crude product was purified by flash chromatography with dichloromethane to dichloromethane/ethyl acetate (80:20) eluant to yield a mixture of the two propenals 15 and 16 in a combined yield of 94\%. The indol-2-ylpropenal 15 (0.18 g, 77\%) was obtained as a yellow solid. Recrystallization from ethyl acetate/light petroleum resulted in yellow rhombs, mp 184-185 ${ }^{\circ} \mathrm{C}$. IR $\left(v_{\max } \mathrm{cm}^{-1}\right): 1667,1601,1260,1117$. UV/Vis $\left(\lambda_{\max }, \mathrm{nm}, \varepsilon, \mathrm{cm}^{-1} \mathrm{M}^{-1}\right): 273(19,700) .{ }^{1} \mathrm{H} \mathrm{NMR}(300 \mathrm{MHz}$, $\left.\mathrm{CDCl}_{3}\right): \delta_{\mathrm{H}} 3.72(3 \mathrm{H}, \mathrm{s}, \mathrm{NMe}), 3.91,3.95(6 \mathrm{H}, 2 \mathrm{~s}, \mathrm{OMe}), 6.21,6.40(2 \mathrm{H}, 2 \mathrm{~d}, \mathrm{~J} 1.9 \mathrm{~Hz}$, indole H5, H7), $6.48(1 \mathrm{H}, \mathrm{dd}$, J $16.4 \mathrm{~Hz}, 7.6 \mathrm{~Hz}, \mathrm{H} 2), 7.36(1 \mathrm{H}, \mathrm{d}, J 16.4 \mathrm{~Hz}, \mathrm{H3}), 7.36,7.43(4 \mathrm{H}, 2 \mathrm{~d}, J 8.7 \mathrm{~Hz}, \operatorname{aryl}), 9.48(1 \mathrm{H}, \mathrm{d}, J 7.6 \mathrm{~Hz}, \mathrm{CHO})$. ${ }^{13} \mathrm{C}$ NMR (75 MHz, $\left.d_{6}-\mathrm{DMSO}\right): \delta_{\mathrm{C}} 31.8$ (NMe), 55.2, 55.6 (OMe), 85.4 (indole C5) 92.9 (indole C7), 125.8 (C2), 140.3 (C3), 127.6, 132.5 (aryl CH), 111.3, 122.3, 128.9, 131.8, 133.6, 141.3, 155.0, 159.6 (aryl C), 193.9 (CO). MS (+El, m/z, \%): $357\left(\mathrm{M}^{37} \mathrm{Cl}, 35\right), 355$ ( $\left.\mathrm{M}^{35} \mathrm{Cl}, 100\right), 326$ (25), 314 (25), 291 (50), 146 (40), 139 (60). Anal. calcd for $\mathrm{C}_{20} \mathrm{H}_{18} \mathrm{ClNO}_{3}$ : C, 67.5; $\mathrm{H}, 5.1 ; \mathrm{N}, 3.9$. Found: 67.6; $\mathrm{H}, 5.3 ; \mathrm{N}, 3.9 \%$.

The indol-7-ylpropenal 16 (40 mg, 17\%) was obtained as a green solid. Recrystallization from ethyl acetate/light petroleum resulted in olive green needles, $\mathrm{mp} 219-22{ }^{\circ} \mathrm{C}$. IR $\left(v_{\max } \mathrm{cm}^{-1}\right): 1678,1574,1146,1046$, 793. UV/Vis $\left(\lambda_{\max }, \mathrm{nm}, \varepsilon, \mathrm{cm}^{-1} \mathrm{M}^{-1}\right): 232(29,000), 272(5,900) .{ }^{1} \mathrm{H}$ NMR $\left(300 \mathrm{MHz}, \mathrm{CDCl}_{3}\right): \delta_{\mathrm{H}} 3.95(3 \mathrm{H}, \mathrm{s}, \mathrm{NMe})$, 4.02, $4.03(6 \mathrm{H}, 2 \mathrm{~s}, \mathrm{OMe}), 6.35,6.86(2 \mathrm{H}, 2 \mathrm{~s}$, indole $\mathrm{H} 5$ and H2), $6.99(1 \mathrm{H}, \mathrm{dd}, J 15.5,7.7 \mathrm{~Hz}, \mathrm{H} 2), 7.42(4 \mathrm{H}, \mathrm{dd}, J$ 8.3, $2.0 \mathrm{~Hz}, \operatorname{aryl}), 8.14(1 \mathrm{H}, \mathrm{d}, J 15.5 \mathrm{~Hz}, \mathrm{H3}), 9.69(1 \mathrm{H}, \mathrm{d}, J 7.7 \mathrm{~Hz}, \mathrm{CHO})$. MS (+El, $m / z, \%): 357\left(\mathrm{M}^{37} \mathrm{Cl}, 35\right) 355$ $\left(\mathrm{M}^{35} \mathrm{Cl}, 100\right), 326$ (25), $324(85), 301$ (50), 261 (20), 251 (20), 160 (30). Anal. calcd for $\mathrm{C}_{20} \mathrm{H}_{18} \mathrm{ClNO}_{3}: \mathrm{C}, 67.5 ; \mathrm{H}$, $5.1 ; \mathrm{N}, 3.9$. Found: $\mathrm{C}, 67.3 ; \mathrm{H}, 5.4 ; \mathrm{N}, 3.7 \%$.

Methyl trans-3-(5,7-dimethoxyindol-4-yl)propen-1-al-2-carboxylate (18) and methyl cis-3-(5,7-dimethoxyindol-4-yl)propen-1-al-2-carboxylate (19). A mixture of methyl 5,7-dimethoxyindole-2-carboxylate 17 (0.107 $\mathrm{g}, 0.455 \mathrm{mmol}$ ) and 3-dimethylaminopropenal $1(0.10 \mathrm{~mL}, 0.91 \mathrm{mmol})$ in dichloromethane $(2.0 \mathrm{~mL})$ was stirred with cooling in a salt-ice slurry. A similarly cooled solution of phosphoryl chloride $(0.09 \mathrm{~mL}, 1 \mathrm{mmol})$ in dichloromethane $(1.0 \mathrm{~mL})$ was added dropwise over 3 min and stirring was continued for $1 \mathrm{~h}$ with cooling below $0{ }^{\circ} \mathrm{C}$. Stirring was then continued at ambient temperature for $50 \mathrm{~min}$ before the solution was re-cooled in a salt-ice slurry and made strongly alkaline with $5 \mathrm{M} \mathrm{NaOH}$. After dilution with water and ethyl acetate the mixture was stirred vigorously for $30 \mathrm{~min}$ at ambient temperature. The mixture was then extracted with further ethyl acetate and the organic phase was washed with water, then brine, and dried $\left(\mathrm{MgSO}_{4}\right)$. Evaporation of the solvent in vacuo gave an isomeric mixture of the title compounds $(0.130 \mathrm{~g}, 99 \%)$ as a yellow powder, consisting of a 5:1 ratio of the trans/cis propen-1-al. Recrystallization from dichloromethane/light petroleum gave methyl trans-3-(5,7-dimethoxyindol-4-yl)propen-1-al-2-carboxylate 18 as crimson prisms, mp 200-202 ${ }^{\circ} \mathrm{C} . \mathrm{Rf}\left(2 \% \mathrm{MeOH} / \mathrm{CH}_{2} \mathrm{Cl}_{2}\right)$ 0.25. IR $\left(\mathrm{v}_{\max } \mathrm{cm}^{-1}\right): 3314,1703,1655,1578,1530,1439,1342,1265,1214$, 1167, 1143, 979, 821, 772, 742. UV/Vis $\left(\lambda_{\max }, \mathrm{nm}, \varepsilon, \mathrm{cm}^{-1} \mathrm{M}^{-1}\right): 240(30,100), 278(8,900), 307(11,400), 337$ (11,700), 380 (14,700). ${ }^{1} \mathrm{H}$ NMR $\left(300 \mathrm{MHz}, \mathrm{CDCl}_{3}\right): \delta_{\mathrm{H}} 3.95,3.97$ and $4.04(9 \mathrm{H}, \mathrm{s}, \mathrm{OMe}), 6.50(1 \mathrm{H}$, s, indole H6), $6.95(1 \mathrm{H}, \mathrm{dd}, J$ 7.9, $16.2 \mathrm{~Hz}, \mathrm{H} 2), 7.41(1 \mathrm{H}, \mathrm{d}, J 1.9 \mathrm{~Hz}$, indole H3), $8.01(1 \mathrm{H}, \mathrm{d}, J 16.2 \mathrm{~Hz}, \mathrm{H3}), 9.13(1 \mathrm{H}, \mathrm{bs}, \mathrm{NH})$, $9.68(1 \mathrm{H}, \mathrm{d}, \mathrm{J} 7.9 \mathrm{~Hz}, \mathrm{CHO}) .{ }^{13} \mathrm{C} N M R\left(75 \mathrm{MHz}, \mathrm{CDCl}_{3}\right): \delta_{\mathrm{C}} 57.1,55.7,52.1$ (OMe), 92.7 (indole C6), 107.6 (indole 
C3), 127.9, 146.7 (C2 and C3), 108.2, 123.6, 127.0, 128.5, 149.8, 156.7 (aryl C), 161.7 (믈 $\mathrm{Me}), 195.1$ (CHO). MS (+EI, m/z, \%): 290 (10), 289 (M, 65), 258 (100), 235 (21), 229 (15), 228 (17), 226 (67), 214 (21), 203 (56), 200 (17), 186 (21). Anal. calcd for $\mathrm{C}_{15} \mathrm{H}_{15} \mathrm{NO}_{5}$ : C, 62.3; $\mathrm{H}, 5.2 ; \mathrm{N}, 4.8$. Found: $\mathrm{C}, 62.5 ; \mathrm{H}, 5.2 ; \mathrm{N}, 4.7 \%$.

Methyl cis-3-(5,7-dimethoxyindol-4-yl)propen-1-al-2-carboxylate (19). ${ }^{1} \mathrm{H} N M R\left(300 \mathrm{MHz}, \mathrm{CDCl}_{3}\right): \delta_{\mathrm{H}} 3.88$, 3.92, $4.02(9 \mathrm{H}, \mathrm{s}, \mathrm{OMe}), 6.16(1 \mathrm{H}, \mathrm{dd}, J 8.6,11.3 \mathrm{~Hz}, \mathrm{H} 2), 6.54(1 \mathrm{H}, \mathrm{s}$, indole H6), $7.06(1 \mathrm{H}, \mathrm{d}, \mathrm{J} 2.3 \mathrm{~Hz}$, indole $\mathrm{H} 3), 7.65(1 \mathrm{H}, \mathrm{d}, \mathrm{J} 11.3 \mathrm{~Hz}, \mathrm{H} 3), 9.04(1 \mathrm{H}, \mathrm{bs}, \mathrm{NH}), 9.78(1 \mathrm{H}, \mathrm{d}, J 8.3 \mathrm{~Hz}, \mathrm{CHO})$.

\section{Acknowledgements}

We thank the Australian Research Council for financial support.

\section{References}

1. Liebscher, J.; Hartmann, H. Synthesis 1979, 241-264.

https://doi.org/10.1055/s-1979-28636

2. Gosmann, M.; Franck, B. Angew. Chem. Int. Ed. Engl. 1986, 25, 1100-1101.

https://doi.org/10.1002/anie.198611001

3. Stepanova, G. P.; Shestakova, T. E.; Stepanov, B. I. Zh. Org. Khim. 1970, 6, 565-567.

4. Xiang, S-K.; Zhang, B.; Zhang, L-H.; Cui, Y.; Jiao, N. Chem. Commun. 2011, 47, 8097-8099. https://doi.org/10.1039/c1cc12220g

5. Hünig, S.; Steinmetzer, H. C.; Ann. Chem. 1976, 1039-1059.

https://doi.org/10.1002/jlac.197619760609

6. Adam, R.; Pindur, U. Chemiker Zeitung 1989, 113, 273-275.

7. Lopez, S.; Rodriguez, V.; Montenegro, J.; Saa, C.; Alvarez, R.; Lopez, C. S.; de Lera, A. r.; Simon, R.; Lazarova, T.; Padros, E. ChemBioChem. 2005, 6, 2078-2087.

https://doi.org/10.1002/cbic.200500148

8. Kearney, A. M.; Vanderwal, C. D. Angew. Chem. Int. Ed. 2006, 45, 7803-7806. https://doi.org/10.1002/anie.200602996

9. Pla, D.; Mills, K.; Joule, J. A.; Albericio, F.; Alvarez, M. ARKIVOC 2009, 260-269.

10. Sisa, M.; Pla, D.; Altuna, M.; Francesch, A.; Cuevas, C.; Albericio, F.; Alvarez, M. J. Med. Chem. 2009, 52, 6217-6223.

https://doi.org/10.1021/jm900544z

11. Kagawa, N.; Sasaki, Y.; Kojima, H.; Toyota, M. Tetrahedron Lett. 2010, 51, 482-484. https://doi.org/10.1016/j.tetlet.2009.11.014

12. Yin, B.; Cai, C.; Zeng, G.; Zhang, R.; Li, X.; Jiang, H. Org. Lett. 2012, 14, 1098-1101. https://doi.org/10.1021/ol300008d

13. Wang, Y-F.; Zhang, F-L.; Chiba, S. Synthesis 2012, 44, 1526-1534. https://doi.org/10.1055/s-0031-1290815

14. Black, D. StC.; Craig, D. C.; Kumar, N.; Wong, L. C. H. Chem. Commun. 1985, 1172-1173. https://doi.org/10.1039/c39850001172

15. Black, D. StC.; Kumar, N.; Wong, L. C. H. Synthesis 1986, 474-476.

https://doi.org/10.1055/s-1986-31678 
16. Condie, G. C.; Channon, M. F.; Ivory, A. J.; Kumar, N.; Black, D. StC. Tetrahedron 2005, 61, 4989-5004. https://doi.org/10.1016/i.tet.2005.03.048

17. Black, D. StC.; Bowyer, M. C.; Kumar, N.; Mitchell, P. S. R. J. Chem. Soc., Chem. Commun. 1993, 819-821. https://doi.org/10.1039/c39930000819

This paper is an open access article distributed under the terms of the Creative Commons Attribution (CC BY) license (http://creativecommons.org/licenses/by/4.0/) 